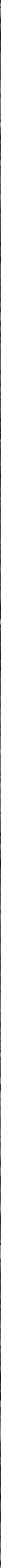




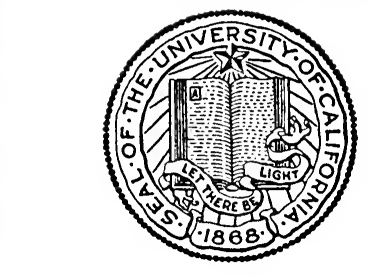

\section{BANCROFT LIBRARY $\diamond$} THE LIBRARY OF THE UNIVERSITY OF CALIFORNIA 


\title{
THE INSTITUTE OF
}

\section{INTERNATIONAL EDUCATION}

\author{
INTERNATIONAL RELATIONS CLUBS
}

SYLLABUS NO. VII

HISPANIC-AMERICAN HISTORY, 1826-1920

By William Whatley Pierson, JR., Ph.D.

Professor of History in the University of North Carolina

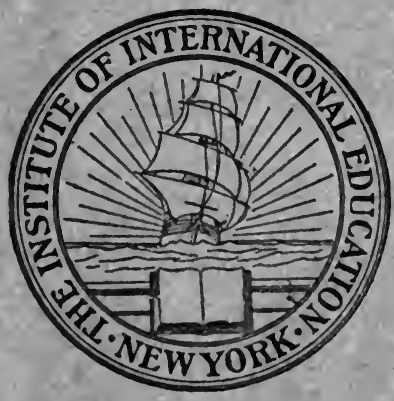

NEW YORK. AUGUST, I 921 


\section{The Institute of International Education}

\section{West I I 7 th Street, New York}

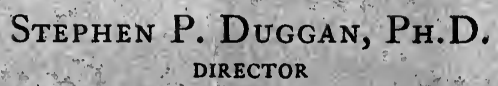

\section{Mary L. WaIte} EXECUTIVE SECRETARY

\section{ADMINISTRATIVE BOARD}

Herman V. Ames

Paul Monroe

L. H. Baekeland John Bassett Moore

Marion Le Roy Burton Henry Morgenthau

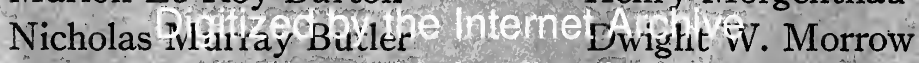
Stephen Pierce Suggan he fundingEroH: Outerbridge Dr. Walter B. IAlowsolt Gofooraltoriry S. Pritchett Alice Duer Miller Mary E. Woolley.

BUREAU DIVISIONS

Europe

Far East

Latin America

Scholarships and Fellowships International Relations Clubs
Stephen P. Duggan

Paul Monroe

Peter H. Goldsmith

Virginia Newcomb

Margaret C. Alexander 
Tick the complement of
Th 26 Piersen. p.

\title{
Institute of International Education
}

\author{
International Relations Clubs
}

$$
\text { Syllabus No. VII }
$$

Hispanic-American History, I $826-1920$

$$
\begin{aligned}
& \text { By William Whatley Pierson, JR., Ph.D. } \\
& \text { Professor of History in the University of North Carolina }
\end{aligned}
$$

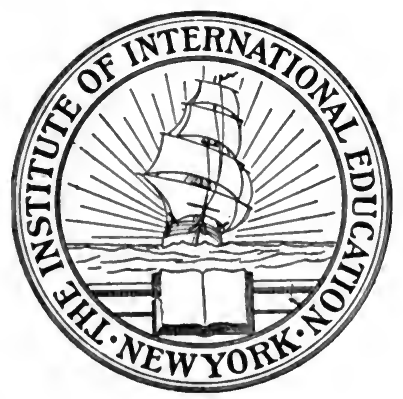

August, I 921 
$\frac{F 1413}{.75}$ 


\section{INTRODUCTORY NOTE}

In the establishment of the independence of South America the United States have the deepest interest. I have no hesitation in asserting my firm belief that there is no question in the foreign policy of this country, which has ever arisen, or which I can conceive as ever occurring, in the decision of which we have had or can have so much at stake.-Henry Clay: The Emancipalion of South America.

In view of the great interest manifested in Hispanic America at the present time, no plea need be made for the study of its history, if, indeed, it be ever necessary to make a plea for the study of history in any field. In respect of the United States, this interest is due in part to the opening of the Panamá canal and to the questions that have arisen between our government and the nations of the Caribbean, and in part to the demands and results of the recent war, which have impressed upon our people the importance of opportunities for trade that formerly either did not exist or were not recognized. Those who have given thought to the subject are convinced that the economic, political, diplomatic, intellectual and social importance of the Hispanic-American countries renders urgent a thorough study of them and a sympathetic understanding of their history, institutions, languages, literature and customs. The appreciation of these considerations, and the new sense of obligation and opportunity that springs from it, seem to mark the dawning of another era in the history of the western hemisphere; for, according to James Bryce, the part that the peoples of the Hispanic-American republics are to play "must henceforth be one of growing significance for the Old World as well as for the New." It may be assumed that this new era will be of a character distinctly inter-american, and it is to be hoped that this recently awakened interest on the part of our people in whatever pertains to the southern countries of America will develop broadly and steadily and will endure throughout the long future.

Students who desire to study the subject more in detail will find valuable aid in the following bibliographies: the several monumental works of José Toribio Medina, covering Chile, Argentina 
and México; P. H. Goldsmith's A Brief Bibliography (The Macmillan Company); the Bibliographie Hispanique, an annual publication of the Hispanic Society of America; and the lists and catalogues of books, pamphlets, periodicals and maps prepared by the Pan American Union and printed by the United States government. The last mentioned are: the lists that relate to Brazil (1901), Central America (1902), and Chile (1903), compiled by P. Lee Phillips; the catalogue of books, periodicals, etc., which may be consulted in the library of the Pan American Union, and which appeared successively in 1905, 1907, 1909 and 1914; and many lists of works that treat of the Hispanic-American countries separately. They cover Argentina, Brazil, Chile, Costa Rica, Cuba, Ecuador, Colombia, México, Perú and Paraguay. A valuable list of bibliographies is given in the articles by C. K. Jones, entitled "Hispanic-American Bibliographies," published in the HispanicAmerican Historical Review (1920-192I). The magazine just alluded to is to be recommended, not only for its own articles and reviews, but also for the bibliographical lists it contains of recently published books and articles that relate to the Hispanic countries of America. Inter-America, founded four years ago by the Carnegie Endowment for International Peace, has published, in its English issues, numerous important articles translated from HispanicAmerican sources, and files of it may be consulted in many libraries.

By permission of the University of North Carolina, certain parts of my Syllabus of Hispanic American History are reproduced here.

\section{William Whatley Pierson, Jr.}

Chapel Hill, North Carolina 


\section{CHAPTER I}

\section{EARLY RELATIONS OF HISPANIC AMERICA WITH THE UNITED STATES: THE MONROE DOCTRINE}

I. Diffusion of revolutionary ideas and political opinions of the United States in South America

2. Part played by Spanish-Americans in the war of independence in the United States

3. Part played by the United States in the Hispanic-American wars of independence; diplomatic relations of United States and the de facto governments and peoples of Hispanic America, 1810-1822; early Pan Americanism of Henry Clay

4. Early ideas as to an American concert

5. Jefferson and John Adams on South America

6. Early statements of the Monroe Doctrine

7. Evolution of Monroe Doctrine during the revolutionary wars; the part of Hispanic America

8. The attitude of the European states toward Hispanic America after the Congress of Vienna

a. Effects of the American revolutionary wars upon European politics and diplomacy

b. The policy of intervention as conceived by Metternich

c. The Holy Alliance and the Concert of Europe

d. Application of the policy of intervention

e. The congresses of Laibach, Troppau, Verona

f. The attitude of Great Britain

9. Recognition of the Spanish-American countries by the United States, 1822

10. The Canning-Rush-Adams correspondence

II. The message of Monroe

12. Reception of the Monroe Doctrine in South America and in Europe

13. The Monroe Doctrine, I823-1828; proposals of alliance made by the South American countries to the United States

14. Their recognition by Great Britain, Spain and other European states

Readings:

Annals of the American Academy of Political and Social Science, July, I9I4

Bigelow, John, American Policy

Bingham, Hiram, The Monroe Doctrine, an Obsolete Shibboleth

Bryce, James, South America, Observations and Impressions: 422-45I

Calderón, F. García, Latin America, its Rise and Progress: 58-85

Chadwick, F. E., The Relations of Spain and the United States (2 Vols.)

Coolidge, A. C., The United States as a World Power 
Edgington, F. B., History of the Monroe Doctrine

Gilman, Daniel C., James Monroe

Hall, A. B., The Past, Present and Future of the Monroe Doctrine (Syllabus No. II of this series)

Hart, A. B., The Monroe Doctrine

Koebel, W. H., British Exploits in South America: 163-254

Manning, W. R., Early Diplomatic Relations between the United States and Mexico

Moore, J. B., Digest of International Law (sections on the Monroe Doctrine)

Paxson, F. L., The Independence of the South American Republics

Quesada, Ernesto, La doctrina Monróe

Robertson, W. S., Reception of the Monroe Doctrine (Political Science Quarterly, I915)

Shepherd, W. R., Bolivar and the United States (Hisp. Am. Hist. Rev. 1918)

Torres, Manuel, An Exposition of the Commerce of South America

\section{CHAPTER II}

\section{POLITICAL THEORIES AND EARLY REPUBLICAN INSTITUTIONS}

I. The monarchial idea versus the republican; opinions of the revolutionary leaders: Bolívar, San Martín, Rivadavia, Belgrano, Sucre, Paez, etc.

2. Early political parties or groups, and their theories

a. Unitary; federalist; conservative; and radical

b. Liberal and conservative writers on politics: Lastarria, Bilbao, Echeverría, Montalvo, Vigil, Sarmiento, Bello, Alberdi, Herrera, Acosta

c. Influence of France on political theorists

3. Political factions

Military; clerical; civilian; lay

4. Party methods and politics

5. Ballots and elections; restrictions of the suffrage

6. Popular apathy in political affairs; personal politics

7. Character of governments

a. Federal and unitary

b. Revolution as a means of political action

8. Early constitutions; separation of powers

9. The office of the executive

a. Constitutional powers in various countries

b. Prestige and dignity of office

c. Early types of executives: tyrants; dictators; liberators; restorers; caudillos; regeneradores

I0. Character and powers of congress; congress versus president; experiments with unicameral legislatures

II. Influence of English and French cabinet systems of government

12. The judiciary in Hispanic America

a. Constitutional powers and position in administration

b. Judicial review of legislation

13. Early conventions and platforms; "plans;" pronunciamentos 
14. Municipal government

a. General characteristics

b. Police systems

c. Public service

d. Prisons

\section{Readings:}

Alberdi, Juan Bautista, Las bases y puntos de partida para la organización politica de la República Argentina

- Estudios económicos

- Del Gobierno en Sud A mérica

Alvarez, Agustin, South America; ensayo de psicología politica

Amunátegui, M. L., Vida de don Andrés Bello

Calderón, F. García, Lalin America, its Rise and Progress: 100-350

Fuenzalida Grandón, Alejandro, Lastarria y su tiempo

Herrera, Julio, Anarcuismo y defensa social

Ingenieros, José, Sociología Argentina

Lastarria, J. V., Lecciones de política positiva en la Academia de Bellas Letras

Pereyra, Carlos, El pensamiento de Alberdi

Sarmiento, D. F., El Facundo

\section{Life in the Argentine Republic}

Shepherd, W. R., Lalin America: 8I-96

Unquera, A., Balbin de, Andrés Bello, su época y sus obras

Books on individual countries

\section{CHAPTER III}

\section{POLITICAL HISTORY, I826-I9I4}

1. The three phases

a. 1826-1850, age of dictators

b. 1850-1876, struggle for stability

c. 1876-, rise of great states and economic progress

2. Typical dictators

a. García Moreno-Ecuador

b. Ramón Castilla-Perú

c. Rosas-Argentina

d. Paez and Guzmán Blanco-Venezuela

e. Santa Anna and Díaz-México

f. Estrada Cabrera-Guatemala

g. Francia and Solano López-Paraguay

h. Melgarejo-Bolivia

3. The states of South America

a. Argentina

(I) The presidency of Rivadavia

(a) Educational and economic reforms

(b) Political parties; federalism versus unitarism 
(c) The war with Brazil; Argentine claims to Uruguay; battle of Ituzaingó; operations of Admiral Brown; the treaty of peace

(d) Overthrow of Rivadavia's government

(2) The problem of caudillism in Argentina; separatist movements within certain provinces; Ramírez, Bustos, López, Quiroga, José Aldao, Ferré, Ibarra

(3) Civil war; conflict between Buenos Aires and the provinces; Dorrego; Lavalle; Rosas; battle of Tablada; triumph of Rosas

(4) The era of Rosas

(a) Methods of government; the mazorca

(b) Exile of the unitarists; resistance of General Paz

(c) Effects of his rule upon the country

(d) Relations with foreign powers; European intervention

(e) Intervention of Rosas in Uruguay; support of Oribe; the siege of Montevideo

(f) Efforts to overthrow Rosas

(5) General Urquiza; the alliance to destroy Rosas; invasion of Argentina; battle of Caseros, I85I

(6) Presidency of Urquiza; constitution of I 853

(7) Separatism in Buenos Aires; Derqui and Mitre; battle of Pavón

(8) Administration of Mitre

(9) Sarmiento and educational reform; increased prosperity; Avellaneda

(I0) President Roca; the southward movement in Argentina; internal improvements

(I I) Juárez Celman; the panic; efforts of Roca and Mitre to prevent civil war; Pellegrini; Sáenz Peña; Roca's second administration

(I2) Boundary disputes with Chile and Brazil; arbitration treaty; economic development; currency legislation

(I3) Contemporary government and politics

(a) Provincial and national powers; right of intervention; state of siege

(b) The federal district of Buenos Aires

(c) Quintana; Figurọa; Roque Sáenz Peña

Readings:

Bunge, A. E., Ferrocarriles argentinos

Chandler, C. L., The Argentine Southward Movement (Bulletin Pan American

Union, 1914)

Escobar, J. B., Los presidentes argentinos

Groussac, Paul, Los que pasaban (biographical)

$\longrightarrow$, Estudios de historia argentina

Hirst, W. A., Argentina

Ingenieros, José, Sociología argentina

Koebel, W. H., Argentina, Past and Present

Lamos, Andrés, La Obra económica de Bernardino Rivadavia

Levene, R., Lecciones de historia argentina

López, V. F., Historia de la República de Argentina (Vols. IX and X)

Martínez, A. B. and Lewandowski, Maurice, The Argentine in the Twentieth Century 
Mérou, Garcia, Historia de la República Argentina

Mitre, B., Historia de San Martín, (4 vols.)

Martínez, Paz, E., Dalmacio Vélez Sarsfield y el código civil argentino

Pennington, A. S., The Argentine Republic

Pilling, William, trans., Historia de Belgrano, (3 vols.)

Ramos Mejí, José N., Rosas y su tiempo, (3 vols.)

Tornquist \& Co., Ernesto, The Economic Development of .Argentina during the Last Fifty Years

b. Brazil

(1) Brazil and Portugal, 1807-1822

(a) Arrival of João VI; political and economic reforms

(b) The kingdom of Brazil; policy toward Uruguay

(c) Anti-Portuguese sentiment in politics

(d) Portuguese revolution of 1820 ; recall of João VI; demand for constitution in Brazil

(e) The regency of Pedro; the revolution; independence of Brazil; establishment of the empire; the constitution

(f) Services of Lord Cochrane.

(2) The reign of Pedro I, I 822-I83I

(a) Absolutist tendencies; operation of the constitution

(b) The character and services of Pedro I; general policies

(c) The revolution in Uruguay; the war with Argentina; invasion of Brazil; battle of Ituzaingó

(d) The Portuguese problem; abdication of Pedro I

(3) The regency, I83 I-1 840

(a) Services of Feijó

(b) Political disorders; problems of federalism; secessionist tendencies in Rio Grande do Sul

(c) Vasconcellos; the Andrades

(d) The emperor declared of age

(4) The reign of Pedro II, 1840-1889

(a) Character, training, political theories

(b) Establishment of order; economic prosperity; educational, parliamentary, administrative, and political progress; Marquis de Paraná, Caxias, the Rio Brancos

(c) Diplomatic policies; intervention in Uruguay, the war against Rosas

(d) The war against Paraguay: alliance of Brazil, Argentina and Uruguay; services of Brazil; general results (see Paraguay)

(e) Anti-slavery movement in Brazil; legislation; political significance

(f) Republican sentiment; Benjamin Constant

(g) Deposition of the emperor; the army question; establishment of the republic

(5) The republic; federal constitution of 1891 ; political parties

(6) Early disorder, 1891-1893, Deodoro da Fonseca, Peixoto, Mello; election of Dr. Prudente de Moraes Barros; progress toward stability 
(7) Administrations of Campos Salles; Rodríguez Alves; Alfonso Penna; boundary disputes and arbitrations with British Guiana and Bolivia

(8) The westward movement in Brazil

(9) Colonization experiments and achievements: state and national

(Io) Contemporary government and politics

\section{Readings :}

Buley, E. C., North Brazil

- South Brazil

Cambridge Modern History (Vol. X, 310-339; Vol. XII, 674-676)

Denis, Pierre, Brazil

Domville-Fife, C. W., The United States of Brazil

Elliott, L. E., Brazil

Fabricatore, Carlo, La Rivoluzione del Bresile

Grossi, V., Storia della Colonizazione Europea al Brazile

Koebel, W. H., British Exploits in South America; 28I-373

Lima, M. de Oliviera, Historia diplcmática do Brazil e-reconhecimiento do Imperio

Martin, P. A., Causes of the Collapse of the Brazilian Empire (Hisp. Am. Hist.

Rev., I92I)

Mulhall, M. G., Rio Grande do Sul and its German Colonies

Pinheiro, C. M., Historia do Brazil (12 vols.)

Ribeiro, João, Historia do Brazil

Silva, J. M. Pereira da, Historia da fundação do Imperio Brazileiro

Varnhagen, F. A. de, Historia Geral do Brazil (Vol. II)

Watson, R. G., Spanish and Portuguese South America (Vol. II, 256-270)

Winter, N. O., Brazil and Her People of Today

c. Chile

(I) Government and dictatorship of Bernardo O'Higgins

(2) Revolutionary disorders; General Freire; party politics; federalism versus unitarism; presidential changes

(3) Success of the pelucones; work of Prieto and Portales; the constitution of 1833

(4) The conservative régime, I83I-I87I; the ten year presidents, Prieto, Bulnes, Manuel Montt, Pérez

(a) The traditions of order

(b) War with the Perú-Bolivia confederation of Santa Cruz; battle of Yungay

(c) Conservative politics and legislation; educational and ecclesiastical problems

(d) War with Spain, I 865

(e) Revival of the liberal party; election of Errázuriz

(5) The problem of the Araucanian Indians

(6) The War of the Pacific

(a) The northern boundary of Chile in history

(b) Discovery and development of guano and nitrate deposits

(c) Immigration of Chileans in disputed region; Chilean capital invested; law of 1842 ; military demonstration at Mejillones 
(d) Treaties respecting disputed territory, 1866, 1874, 1875; the Perú-Bolivia treaty of alliance of 1873 ; international aspects of the situation; Argentina involved; Chilean military and naval preparations

(e) Alleged treaty violation by Bolivia; the question of taxes on nitrate; military occupation of Antofagasta; war between Chile and Bolivia; failure of Peruvian mediation; Perú involved in the war; attitude of Hispanic-American countries

(f) The war on the sea; Prat and Grau; Battle of Angamos; blockades; international complications

(g) The war on land; comparative resources; battles of Dolores and Tarapacá; incapacity of Prado and Daza; retreat from Camarones; campaign in Perú; battles of Chorillos and Miraflores; guerilla warfare against army of occupation

(h) The treaty of Ancón; the Tacna and Arica provision; profits of the war; prestige of Chile

(i) Chilean politics during the war; Pinto and Santa María

(7) Administration of Santa María; liberal measures

(8) Balmaceda and the struggle between president and congress

(a) Political and economic causes

(b) The constitutional question; operation of the cabinet system

(c) The civil war: activities of the navy under Jorge Montt; canpaign around Iquique; battles of Concón and Placilla

(d) The "Itata" affair; the attack on sailors of the "Baltimore"

(9) The administration of Jorge Montt; reconstruction; diplomatic relations between Chile and the United States; relations with Bolivia; Chile and the execution of the Treaty of Ancón.

(Io) Boundary dispute with Argentina; treaty of arbitration and conciliation; the "Christ of the Andes"

(I I) Contemporary government and politics
(a) The cabinet system in Chile
(b) Contemporary political parties
(c) Local government

(12) Economic, educational, and social progress

Keadings:

Amunátegui, M. L., and Vicuña Mackenna, Benjamin, La dictadura de O'Higgins

Barros Arana, Diego, Historia general de Chile (12 vols.)

- Historia de la guerra del Pacifico

Belaúnde, Victor Andrés, Nuestra cuestión con Chile

Blanlot Holley, Anselmo, Historia de la paz entre Chile y el Perí

Borchard, E. M., Opinion on the Controversy between Peru and Chile

Bulnes, Gonzalo, La Guerra del Pacífico (10 vols.)

- Las causas de la guerra entre Chile y el Perú

Caivano, Tomás, Narración histórica de la guerra de Chile con el Perí y Bclivia

- Historia de la guerra de América, entre Chile, Perú y Bolivia

Calderón, F. García, Latin America, its Rise and Progress: 164-179 
Egaña, Rafael, Historia de la dictadura y la revolución en Chile en I89I

- The Tacna and Arica Question

Gutiérrez, Alberto, La Guerra de 1879

Hancock, A. U., A History of Chile: 200-455

Macy, Jesse and J. W. Gannaway, Comparative Free Government: 663-672

Markham, C. R., The War between Peru and Chile

Maúrtua, V. M., The Question of the Pacific

Paz Soldán, Mariano Felipe, Narración histórica de la guerra de Chile contra el Perú y Bolivia

Pérez Canto, Julio, El conflicto después de la victoria

Reinsch, P. S., Parliamentary Government in Chile (American Political Science Review: Vol. III, 507 et seq.)

Scott Elliott, G. F., Chile

Vi ‘ũ̃a Mackenna, Obras históricas sobre Chile

—. La guerra del Pacífico

d. Uruguay

(I) The Brazilian occupation and administration; Uruguayan resistance; the expedition of the "Thirty-Three"; war between Argentina and Brazil; battle of Ituzaingó

(2) The independence of Uruguay; constitution of 1830

(3) Political parties in Uruguay; Lavalleja, Rivera, Oribe

(4) Relations of Uruguay with Rosas; siege of Montevideo; participation of Uruguay in the overthrow of Rosas

(5) General Flores; the Brazilian intervention of 1865

(6) War with Paraguay (see Paraguay).

(7) Progress toward political stability; President Cuestas, 1897-1903

(8) Economic and educational development; ecclesiastical legislation

(9) Contemporary government and politics; José Batlle y Ordóñez

Readings:

Acevedo, P. B., Historia de la República Oriental del Uruguay

Araújo, Orestes, Gobernantes del Uruguay (2 vols.)

Koebel, W. H., Uruguay

Mascaró, Pedro, Revista del Archivo Administrativo ó collección de documentos para servir al estudio de la historia de la República Orental del Uruguay (3 vols.)

Miranda, J. O., Compendio de historia nacional

Mitre. M. de Vedia, y, El gobierno de Uruguay

San Martín, J. Zorrilla de, La epopeya de Artigas

e. Perú

(I) Bolívar as President of Perú; rivalry of Santa Cruz and La Mar; relations with Ecuador

(2) Administration of Gamarra; civil war, 1833-1835; Bolivian intervention; partition of Perú; the Perú-Bolivian confederation

(3) The Chilean attack on the confederation; battle of Yungay; continued civil war

(4) Ramón Castilla; constitution of 1860

(5) Pezet and the Spanish intervention; Prado; battle of Callao 
(6) Balta; Prado; financial difficulties

(7) The alliance with Bolivia, 1873

(8) War with Chile; the Peruvian case (see Chile)

(9) Dictatorship of Caceres; the "Peruvian Corporation"; revolution of 1895; Piérola

(10) Efforts of Perú to have Treaty of Ancón fulfilled

(II) Contemporary government and politics

Readings:

Enock, C. R., Peru

Lorente, Sebastián, Historia del Perú desde la Proclamación de la independenciu Markham, C. R., A Hislory of Peru

Martin, P. F., Peru in the Twentieth Century

René-Moreno, Gabriel, Bolivia y Perí

Riva Agüero, José de la, La historia en el Perú

Vivian, E. C. H., Peru

Wright, M. R., Peru

f. Bolivia

(I) Presidency of Sucre; Bolívar's constitution

(2) Dictatorship of Santa Cruz; formation of the Perú-Bolivia confederation

(3) The war with Chile, 1837-1839

(4) Ballivián as dictator; Peruvian aggressions, $184 \mathrm{I}$; battle of Yngavi; relations between the two countries

(5) Belzú; Linares; Melgarejo; Morales; Daza

(6) The War of the Pacific (see Chile)

(7) Campero; Pacheco; Arce; Alonso; Pando; sale of the Acre territory

(8) Contemporary government and politics

Readings:

Guzmán, A., Libertad o despotismo en Bolivia

López, M. O., Bosquejo de la historia de Bolivia

Valdés, R. S., Estudio hustórico de Bolivia

Walle. Paul, Bolivia

Wright, M. R., Bohivia

g. Paraguay

(I) The rule of Francia, $1813-1840$

(a) Personality and character of Dr. Francia

(b) Attitude toward foreigners; diplomatic isolation

(c) Maintenance of order; tyranny; personal achievements

(d) State socialism; church policies

(e) Francia and the Indians

(2) Dictatorship of Carlos Antonio López

(a) Changes in foreign policy

(b) The problem of river navigation and trade

(c) Foreign interventions; relations with the United States, Brazil Great Britain

(d) Nepotism 
(3) Francisco Solano López as dictator, 1862-1870

(a) The military spirit in Paraguay

(b) Ambitions and preparations of the dictator

(c) The dispute with Brazil respecting the intervention in Uruguay

(d) The war with Brazil and Uruguay; invasion of Matto Grosso

(e) Violation of Argentine territory and neutrality; war with Argentina

(f) Invasion by the allies; under Mitre; under Caxias; battles around Humaitá and Asunción; death of López, 1870; end of the war; Brazilian occupation of Paraguay

(4) Paraguay since the war; social and political conditions; immigration;

Domínguez; Gondra; Baez

Readings:

Découd, J. S., Paraguay

Domínguez, Manuel, El alma de la raza

Funes, Gregorio, Historia civil del Paraguay

Hardy, M. L., Paraguay

Koebel, W. H., Paraguay

- In Jesuit Land

Macdonald, Alexander K., Picturesque Paraguay

Mitre, B., Guerra del Paraguay

Nabuco, Joaquín, La guerra del Paraguay

O'Leary, J. E., Nuestra epopeya

Pereyra, Carlos, Francisco Solano López y la guerra del Paraguay

Posada, Adolpho, La República del Paraguay

Robertson, J. P., and W. P. Robertson, Letters on Paraguay

Thompson, George, The War in Paraguay

Washburn, C. A., History of Paraguay (2 vols.)

Yubero, G., El Paraguay moderno

h. Colombia

(I) Parties and politics, I822-1830; relations of Bolívar and Santander

(2) Separation of Venezuela and Ecuador from the Granadine confederation

(3) Political disorders; Nueva Granada (I 832); Santander as president; secessionist tendencies

(4) Herrán-Mosquera régime; conservative successes; relations of church and state

(5) Constitutional changes; the problem of Panamá

(6) Colombia under Mosquera; civil war, 1875-1876

.(7) Administration of Núñez, I879-1883, I 885-1891; constitution of I 886

(8) Civil war, 1899-1902

(9) Colombia and the isthmian canal; concessions; the Hay-Herrán treaty, the Panamá revolution; Marroquín

(10) The Colombian grievance against the United States; relations with the Roosevelt, 'Taft, Wilson, Harding administrations

(II) The Reyes administration

(I2) Contemporary government and politics 


\section{Readings:}

Arboleda, Gustavo, Historia contemporánea de Colombia

Eder, P. J., Colombia

Levine, V. C., Colombia

Núñez, Rafael, La Ripubligue de Colombia

Otero, J. M. Quijano, Compendio de la historia patria

Petre, F. L., The Republic of Colombia

Posada, Eduardo, El canal de Panamá

Sarmiento, J. M. Pérez, Colombia

Scruggs, W. L., The Colombian and Venezuelan Republics

i. Venezuela

(I) Separation from Colombia

(2) The ascendancy of General Paez, 1830-1846; administrations of Vargas and Soublette

(3) The Monagas brothers; abolition of slavery

(4) Federalism, 1858-1868

(5) Dictatorship of Guzmán Blanco, 1870-1889

(6) Crespo and Andrade

(7) The Venezuelan boundary dispute

(a) The Guiana boundary in history

(b) Appeal to the United States on the basis of the Monroe Doctrine relations of the United States and Great Britain

(c) The arbitration

(8) Dictatorship of Castro

(9) Second Venezuelan crisis; blockade by Great Britain, Germany and Italy; arbitration

(I0) Overthrow of Castro; presidency of Gómez

Readings:

Aguado, Pedro de, Historia de Venezuela

Alvorado, Lisandro, Historia de la revolución federal en Venezuela

Baralt, R. M., and R. Díaz, Resumen de la historia de Venezuela (2 vols.)

Carbonell, Diego, The Natural Sciences in Venezuela

Dalton, L. V., Venezuela

Fortoul, José Gil, Historia constitutional de Venezuela: Vol. II

Guínan, G., Historia contemporánea de Venezuela

Rojas, J. M. de, Bosquejo histórico de Venezuela

Scruggs, W. I., The Colombian and Venezuelan Republics

j. Ecuador

(I) Independence; the work of General Flores

(2) The presidency of Rocafuerte

(3) Second administration of Flores; civil war

(4) Constitutional changes; Urbina and Robles

(5) Dictatorship of García Moreno

(a) Reforms in taxation and administration; public improvements

(b) Church policies and legislation

(c) Attitude toward Europe 
(d) Assassination of García Moreno; disorders

(6) Borrero; Veintemilla; Camano; Flores; Cordero:

(7) Contemporary government and politics; boundary disputes

Readings:

Calindo, E. V., La integridad territorial de la República del Ecuador

Cevallos, R. F., Compendio de la historia del Ecuador

Destruge, C., Ecuador

Enock, C. R., Ecuador

Mejía, José, Ecuador

Moncayo, Pedro, El Ecuador de I825 á I875, sus hombres, sus instituciones, y sus leyes

Wolf, Teodoro, Geografía y geología del Ecuador

4. México

a. The empire of Iturbide; transition to republic; part of Santa Anna

b. Political disorders; Victoria; Guerrero; federalism and unitarism; foreign interventions

c. Relations with Texas

(I) Migration of citizens of the United States

(2) Slavery in Texas; Mexican legislation respecting slavery and immigration

(3) The Texas revolution; independence of Texas

d. The war with the United States

(I) The Texas boundary dispute

(2) Annexation of Texas

(3) The war; military campaigns; governmental changes in México

(4) The treaty of peace; Mexican losses

e. The "War of the Reform"

(I) The career of Santa Anna

(2) Political parties and rival platforms; anti-clerical legislation; constitution of 1857

(3) Resort to force; the campaign; church party defeated; Juárez

f. Maximilian

(I) Appeal of clerical party to Napoleon III; his plans

(2) The economic aspect; suspension of payment on foreign claims and debts; joint expedition of Great Britain, Spain and France; withdrawal of Great Britain and Spain

(3) Establishment of the empire; its troubles and failure; republican resistance; withdrawal of French support .

(4) Attitude of the United States

g. Republican restoration; factional disputes following death of Juárez

h. The Díaz régime

(1) The first term, 1876-1880; strong government

(2) Administration of González

(3) Resumption of office by Díaz (I884-1910)

(4) Character of the Díaz rule; achievements in internal improvements; education; industry; the administration; the jefes politicos; suppression of opposition; reëlections I $888,1892,1896,1900,1904,1910$ 
(5) Work of Limantour; Romero; Corral

(6) Decay of the system; campaign of Madero

i. The revolution-contemporary period

(I) Succession of governments; Madero; Huerta; Carranza; Villa; Obregón

(2) Social, political, economic, racial aspects of the revolution

(3) The United States a factor in the government of México; problem of recognition; embargo on arms; intervention

(4) The alien investor and concessionaire; safety of property and person in México

(5) The constitution of 1917; problem of the land; petroleum controversy

j. Diplomatic relations with the United States; with Japan; with Germany

Readings:

Alamán, L., Historia de Méjico

Alvorado, Salvador, La reconstrucción de México

Bancroft, H. H., History of Mexico (6 vols.)

- Biography of Porfirio Diaz

Bulnes, Francisco, El verdadero Juárez y la verdad sobre la intervención y el imperio

- El verdadero Díaz y la Revolución

Burke, U. R., A Life of Benito Juárez

Chamberlain, J. P., Property Rights under the New Mexican Constitution (Pol.

Sci. Quar., 1917)

Estrada, R., La revolución y Francisco I. Madero

Fornaro, Carlos de, Mexico and Carranza

Fortier, A., and J. R. Ficklen, Central America and Mexico

García, Genaro, Juárez (Refutation of Bulnes)

- (ed.), Documentos históricos Mexicanos (7 vols.)

Gibbon, T. E., Mexico under Carranza

González, A. P., La Revolución y sus héroes

Hannay, David, Díaz

Kendall, J. J., Mexico under Maximilian

Lara, L. Gutiérrez de, and E. Pinchon, The Mexican People

Martin, P. F., Maximilian in Mexico

Noll, A. H., From Empire to Republic

- History of Mexico

Obregón, T. Esquivel, Democracia y personalismo

Priestley, H. I., Modern Mexican History (Syllabus No. VI in this series)

Ramírez, J. F., México durante su guerra con los Estados Unidos

Riva Palacio, Vicente (ed.), México á través de los siglos (4 vols.)

Rives, George L., The United States and Mexico, $1821-1848$ (2 vols.)

Romero, Matías, The United States and Mexico

Rowe, L. S., The Mexican Revolution, its Causes and Consequences (Pol. Sci. Quar., 1912)

Smith, Justin H., The Annexation of Texas

-, Our War with Mexico (2 vols.)

Stevenson, S. Y., Maximilian in Mexico-A Woman's Reminiscences 
Trowbridge, E. D., Mexico Today and Tomorrow

Valdés, M., Memorias de la guerra de la reforma

5. The Central American states

a. Costa Rica, Guatemala, Honduras, Salvador and Nicaragua

(I) Race distribution; resources; social conditions

(2) Projects of union: I823-I839; I842; $1848 ; 1852 ; 1862 ; 1872 ; 1876$; I $887 ;$ I $889 ;$ I $895 ;$ I 897

(3) The confederation; Arce; Morazán; the unionists and separatists

(4) The ascendancy of the conservatives, 1839-1871; Rafael Carrera

(5) William Walker and Central America

(6) Central America and the Mosquito coast; Great Britain and the United States; the Clayton-Bulwer Treaty; subsequent negotiation

(7) Political and governmental problems

(a) Revolution as a mode of expressing political dissent

(b) The harboring of political refugees; revolutions prepared on foreign soil

(c) Dictators in Central American history

(8) Political history

(9) The peace conference of 1907; influence of the United States and Mexico

(Io) Establishment of the Central American court of justice and arbitration

(a) Organization and composition; important cases

(b) The case against Nicaragua, 1917; disruption

(II) The United States and Nicaragua; intervention; treaty of 1916; the Meléndez doctrine

Readings:

Barrantes, F. Montero, Elementos de historia de Costa Rica

Blakeslee, G. H., (ed.), Mexico and the Carribean (W. E. Browning, The Central American Republics and their Problems)

Fortier, A., and J. R. Ficklen, Central America and Mexico

Gavidia, F., Historia moderna del Salvador

Guardia, G. F., Costa Rica

Guzmán, F. A. de Fuentes y, Historia de Guatemala

Koebel, W. H., Central America

Martin, P. F., Salvador of the Twentieth Century.

Munro, D. G., The Five Republics of Central America

Montúfar, Lorenzo, Walker en Centro América

Palmer, Frederick, Central America and its Problems

Peralta, D. M. M. de, Costa Rica y costa de mosquitos

Ramírez, M. Castro, Cinco años de justicia centro-americana

Scroggs, W. O., Filibusters and Financiers

Villafranca, Richard, Costa Rica

Winter, N. O., Guatemala

6. The insular republics

a. Cuba

(I) Cuba in the early part of the nineteenth century; Spanish administration 
(2) Plans made in South America for the revolutionizing of Cuba; the Panamá congress

(3) Cuba in diplomacy: attitude of the United States; opinion in Cuba for annexation; efforts of Great Britain and France to secure Cuba

(4) Slavery in Cuba

(5) Filibusters; Narciso López

(6) The "Black Warrior" incident; the Ostend manifesto, 1854

(7) The ten years' war, 1868-1878

(a) Causes of the revolt; resistance of Spain; Prim; Cánovas

(b) Relations of Spain and the United States; the "Virginius" affair; the United States and the Cuban insurgents

(c) The problem of reform; Cuban demands

(d) Quesada; Maceo; García; Martí

(8) The Cuban revolution of 1895

(a) Administration of Martínez Campos

(b) General Weyler and the reconcentrado policy

(9) The Spanish-American War

(a) Interests of the United States in Cuba; protests against Spanish practices

(b) Destruction of the "Maine"

(c) The war; relations with the Cubans

(d) Status of Cuba in the Treaty of Paris

(10) Military occupation by the United States

(a) Services of General Wood

(b) Progress of the island: order; sanitation and public health; social conditions; public improvement; education; finances and industries

(c) The constitutional convention; political parties

(d) The Platt Amendment

(e) Investments of citizens of the United States

(II) Republican government in Cuba

(a) Administration of Estrada Palma

(b) The second intervention of the United States; policies of Governor Magoon

(c) José Miguel Gómez; Menocal

(d) Diplomatic and economic relations with the United States

(e) The problem of self-government in Cuba

Readings:

Annual Report of the United States Secretary of War, 1902-1906

Cabrera, R., Cuba and the Cubans

Caldwell, R. G., Lopez Expeditions to Cuba, $1848-185 I$

Callahan, J. M., Cuba and International Relations

Canini, I. E., Four Centuries of Spanish Rule in Cuba

Forbes Lindsay, C. H., Cuba and her People of Today

Hill, R. T., Cuba and Porto Rico

Johnson, W. F., The History of (uba (5 vols.)

Jones, C. L., Caribbean Interests of the United Shates 
Ortiz, Fernando, Los negros esclavos

Quesada, Gonzalo de, The War in Cuba

Report of the Military Governor of Cuba (8 vols.)

Robinson, A. G., Cuba and the Intervention

Saco, José Antonio, Historia de esclavitud desde los tiempos remotos hasta nuestros dias

Sagra, Ramón de la, Historia de la ısla de Cuba (13 vols.)

Verrill, A. H., Cuba Past and Present

Watterson, Henry, History of the Spanish-American War

Wood, Leonard, The Military Government of Cuba (Am. Acad. of Pol. and Soc. Sci., 1903)

Wright, I. A., Cuba.

Zaragoza, Z., Las insurrecciones en Cuba

b. Haiti and Santo Domingo

(I) Monarchy and republicanism in Haiti and Santo Domingo

(2) Social and racial problems

(3) Political disorders; character of the political revolutions

(4) International relations

(a) Financial conditions, foreign claims

(b) Interventions

(c) Relations of Santo Domingo and the United States; the Monroe Doctrine as applied to the Caribbean

(d) Haiti and the United States

(5) Attitude toward the United States

(6) Contemporary government and politics

Readings:

Eves, C. A., West Indies

Fiske, A. K., West Indies

García, José Gabriel, Compendio de la Historia de Santo Domingo

Hazard, Samuel, Santo Domingo, Past and Present

Hollander, J. H., Report on the Debt of Santo Domingo (Sen. Ex. Document, Ist session, 59th Congress)

Léger, J. N., Haiti, Her History and Her Detractors

St. John, Spencer, Haiti, the Black Republic

Schoenrich, Otto, Santo Domingo

7. Panamá

a. Secessionist tendencies in Panamá

b. The revolution; recognition by the United States

c. The republic; the canal treaty

d. Relations with Colombia and the United States

e. Boundary disputes with Costa Rica; arbitration

Readings:

Abbott, W. J., Panama and the Canal

Bishop, F., Panamá, Past and Present

Bunau-Varilla, Philippe de, Panama; The Creation, Destruction and Resurrection 
Bunau-Varilla, Philippe de, The Great Adventure of Panama

Gause, F. A., and C. C. Carr, The Story of Panuma

Villegas, A. R. de, The Republic of Panama

General readings for political history

Akers, C. E., History of South America

Amunátegui, M. L., Ensayos biographicos (4 vols.)

Calderón, García, Latin America: 86-231

Cambridge Modern History (Vol. XII, 672-689)

Carbonell, Miguel A., Hombres de nuestra América

Colmo, A., Los paises de la América latina

Dawson, T. C., The South American Republics (2 vols.)

Dodd, W. F., Modern Constitutions (2 vols.)

Domville-Fife, Great States of South A merica

Enock, C. R., The Republics of Central and South America

Koebel, W. H., South America

Opisso, Alfredo, Historia de España y de las Repúblicas Latino-Americanas (25 vols.)

Porter, R. P., The Ten Republics

Rodriguez, J. I., American Constitutions

Shepherd, W. R., Hispanic Nations of the New World; A Chronicle of Our Southern Neighbors

Sweet, W. W., History of Latin America

\section{CHAPTER IV}

\section{RELATIONS WITH ONE ANOTHER AND WITH EUROPE}

I. Boundary disputes and commissions; the principle of uti possidetis de 1810

2. Filibustering expeditions and reprisals

3. The status of Uruguay

4. The war against Paraguay

5. The Chile-Perú-Bolivia war; the Tacna-Arica question

6. International standing of Latin America

7. The problem of unity

a. Proposals for a league of states of Spanish origin

b. Proposals for inclusion of Brazil in this league

c. Congresses of Hispanic-American countries: Panamá (1826), Lima (1848, 1864, 1897), Santiago de Chile (1 856)

d. Programmes of arbitration, proposals for codification of international law for the Americas

e. Congresses for health and sanitation conventions: Rio de Janeiro (1887, 1906), Lima (1888), Washington (1902, 1905), México City (1907), San José de Costa Rica (1909)

f. Scientific congresses: Buenos Aires (1898), Montevideo (I901), Rio de Janeiro (1905), Santiago de Chile (1908), Washington (1916)

g. Control of river commerce, the international rivers

8. Central American affairs; arbitration agreement 
9. The so-called A. B. C. Alliance

Io. Relations with Europe

Diplomatic; economic; cultural

II. European interventions in Hispanic-American affairs

Examples of European intervention: France and Great Britain at Buenos Aires and Montevideo; Spain and France in México; France, Great Britain and Spain in México; Spain in the Dominican Republic and Perú; Great Britain at Corinto; Germany, Great Britain and Jtaly in Venezuela

Readings:

Alvarez, A., Le droit international américain

Calderón, García, Latin America: $335^{-350}$

Cambridge Modern History: Vol. XII, 689-702

Koebel, W. H., The South Americans: 4I-63

Lima, M. de Oliviera, La sociedad de las naciones americanas en el derecho de gentes (Revista de Derecho, Historia y Letras)

Lobo, Helio, O Tribunal Arbitral. Brasileiro-Boliviano

Moore, J. B., Brazil and Peru Boundary Question

Quesada, Ernesto, La evolución del panaméricanismo

Shepherd, W. R., Hispanic Nations of the World; 96-106

Torres Caicedo, José María, Unión latino-americana

Urrutia, F. J., La evolución del principio de arbitraje en América

\section{CHAPTER V}

\section{LATER DIPLOMATIC AND POLITICAL RELATIONS WITH THE UNITED STATES}

I. Development and extension of the Monroe Doctrine

a. The Jackson-Van Buren attitude

b. Polk's revival, interpretation, and restriction

c. Monroe Doctrine in the fifties

(I) Connection with slavery issue

(2) The Clayton-Bulwer Treaty and the Monroe Doctrine

d. The Maximilian episode; attitude of Secretary Seward

e. The United States and the Chilean war with Spain

f. Grant and the Nationalization of the Doctrine

g. The Santos claim in Ecuador; Alsop claim in Chile

h. Expressions of opinion, and policy by Hayes, Garfield, and Blaine

i. Cleveland-Olney extension; the Venezuela crisis

j. Monroe Doctrine and imperialism

k. Roosevelt-Taft period; "paramount interests"; the protectorates

(I) The second Venezuela crisis

(2) The Monroe Doctrine and the Caribbean; Central America; the Hague conference of 1907

(3) Influence of the expansion in the Philippines on the doctrine

(4) The Magdalena Bay incident of 1912; Lodge Resolutions 
1. Wilson doctrine; Mobile Speech, 1913; Mexico; the Caribbean

m. Monroe Doctrine and claims against Hispanic-American countries

(1) Contractual: Alsop, Cerutti, Landreau

(2) Tortuous: case of Moréno; Benton case; Renton case

n. The Monroe Doctrine and the recent war

Readings:

Appropriate sections of Edgington, Bingham, Hart, Bigelow

American Foreign Relations

Barrett John, Latin America of Today

Bonilla, Policarpo, Wilson Doctrine

Hall, A. B., The Monroe Doctrine and the Great War

Lobo, Helio, De Monröe á Rio Branco

Moore, J. B., A Digest of International Law: Vol. VI, 368-604; 714-715

- Principles of American Diplomacy: 246-269

Reddaway, W. F., Monroe Doctrine

Sáenz Peña, Derecho público americano

Vicuña Mackenna, B., Historia de la Administración Montt

Wilson, G. G., The Monroe Doctrine after the War (League of Nations, Vol. I, No. 5)

2. Hispanic-American attitude toward the United States

a. In politics and diplomacy

b. In commerce

\section{Readings:}

Bulnes, F., L'Avenir des nations hispano-américaines

Gondra, César, Los Estados Unidos y las naciones americanas

Merios, S. R., América latina ante el peligro

Sotolongo, F. C., El imperialismo norte-americano

Ugarte, Manuel, El porvenir de la América Española

Weyl, W. E., American World Policies: Chap. XV

3. Efforts at coöperation and friendship

a. Evolution of Pan Americanism

b. The Pan American Union

(I) Organization and purposes

(2) Control and accomplishments

c. Pan American congresses: Washington (1889); México City (1902);

Rio de Janeiro (1906); Buenos Aires (1910)

d. Interamerican financial congresses: Washington (1915); Buenos Aires (1916)

e. The peace and arbitration treaties

f. Intellectual relations; scientific congresses, increase of trade and travel; exchange of teachers and college professors

g. Proposals of an interamerican league of nations

4. The Drago doctrine and the Porter doctrine

5. Hispanic America at the Second Hague Conference 


\section{Readings:}

Drago, L. M., La República Argentina y el caso de Venezuela

Hull, W. L., The United States and Latin America at the Hague

Kennedy, Crammond, The Drago Doctrine (North American Review, 1907)

Laspiur, E. Sarmiento, La doctrina Drago y la locución de plano empleado por Calvo

Moulin, H. A., La doctrine de Drago

Quesada, Ernesto, La doctrina Drago (Revista de Universidad de Buenos Aires, 1919)

Vivot, A. N., La doctrina Drago

6. The Platt Amendment; relations with Cuba; interventions

7. Caribbean interests of the United States

a. Political and economic conditions in the Caribbean area; effects and influences of the Spanish-American War

b. Strategic importance; United States as a Caribbean power

(I) Porto Rico as a dependency

(2) Territorial government; the insular cases; the question of citizenship

(3) The Virgin Islands

c. Dominant position of the United States

(I) In commerce

(2) Financial agreements with Santo Domingo, Haiti and Nicaragua

(3) The Panamá canal as a factor in the problem; status of the Republic of Panamá with respect to the United States

(4) Naval bases of the United States; lease of the Corn Islands; the Bryan-Chamorro treaty

(5) Interventions of the United States; the quasi-protectorates

d. Relations between the United States and Venezuela, Colombia, Central America

e. Attitude of Caribbean peoples toward the United States; problem of selfdetermination

f. Contemporary tendencies

\section{Readings:}

Arili, B. González, La República Dominicana y los Estados Unidos

Blakeslee, G. H., (ed.), Mexico and the Caribbean

Booy, Theodoor de, and Faris, The Virgin Islands

Bonsal, S., The American Mediterranean

González, Salvador Rodríguez, El Golfo de Fonseca en el derecho público centroaméricano

- L La doctrina Meléndez

Henríquez Ureña, M., Los Estados Unidos y la República Dominicana

Jones, C. L., The Caribbean Interests of the United States

8. The isthmian canal

a. Treaties and plans for construction; possible routes

b. The French enterprise; failure and scandals

c. The United States and the canal

(I) The Clayton-Bulwer Treaty; treaties with Nicaragua 
(2) Attitude toward the French project

(3) Influences of the Spanish-American war upon the United States

(4) The Hay-Pauncefote treaty

d. Negotiations with Colombia for canal concession

(1) Selection of Panamá route; proposed purchase of French company's rights and equipment

(2) The Hay-Herrán treaty

(3) Rejection of treaty by Colombian senate

e. Secession of Panamá

(I) The revolution in Panamá

(2) Alleged activities of the French company

(3) Protection of the Panamá railroad by the United States under treaty of 1846 ; success of the revolution

(4) Recognition of Panamá by the United States

(5) The Hay-Bunau-Varilla treaty

f. Construction of the canal, 1904-1915

g. Possible economic and political effects

h. The Colombian grievance against the United States; diplomatic developments; proposed settlement; treaty ratified by United States Senate, 1921

9. Wilson administration

a. Hispanic-American policy

b. Relations with Mexico

c. Achievements and criticism

Readings:

Annals of American Academy of Political and Social Science, July, 1914

Barrett, John, The Panama Canal; What It Is, What It Means

Bishop, Farnham, Panama, Past and Present

Bryce, James, South America: 484-520

Calderón, García, Latin America: 298-312

Chandler, C. L., Inter-American Acquaintances

Flack, H. E., Spanish American Diplomatic Reiations preceding the War of 1808

Gause, F. A., and C. C. Carr, The Story of Panama

Latané, J. H., America as a World Power: 255-285

- The United States and Latin America; 26I-334

Lockey, J. B., Pan Americanism, its Beginnings

Maúrtua, La idea panamericana y la cuestion del arbitraje

Moore, J. B., Principles of A merican Diplomacy: 365-419

United States Senate Document $\cdot$ No. 744,6 Ist Congress, 3 d session

Usher, R. G., Pan-Americanism

Williams, M. W., Anglo-American Isthmian Diplomacy

The New Pan Americanism, Parts I, II, and III (World Peace Foundation) 


\section{CHAPTER VI}

\section{TRADE RELATIONS OF HISPANIC AMERICA AND THE UNITED STATES}

I. Origins of trade

2. Development of trade during the nineteenth century

a. Comparative predominance of the United States to about 1850

b. Disruption of trade during War of Secession

c. Increased European competition after Franco-Prussion war

3. History of trade in the twentieth century

4. Volume of contemporary trade, export and import, with United States; with Europe

5. Character of the trade

a. Standard articles imported and exported

b. Non-competitive goods and raw products

c. Competitive goods

6. Purchasing power of Hispanic-American countries

7. Misconceptions, current in United States, as to Hispanic-American habits of business

8. Obstacles in the way of trade

a. Lack of merchant marine

b. Established habits and traditions of trade

c. Ignorance of market and the accepted methods of trade

(I) Market demands

(2) Transportation problems

(3) Tariff administrations

d. Long term credits

e. Lack of organization to secure the trade

9. Methods for improvement

Io. The Webb-Pomerene Act

Ir. Effects of the European war of 1914; construction of the Panamá Canal

12. Increase of American business interests in Hispanic America

Readings:

Atlas América-latina

Aughinbaugh, W. E., Selling Latin America

Austin, O. P., Trading with our Neighbors in the Caribbean

Babson, R. W., The Future of South America

Bonsal, Stephen, The American Mediterranean

Bott, Ernesto J. J., El Comercio entre los Estados Unidos y la América latina durante la gran guerra

Chandler, C. L., Inter-American Acquaintances

Cooper, C. S., Understanding South America

Commerce Reports (Daily Consular and trade reports, Bureau of For. and Dom. Trade, Dept. of Commerce)

Filsinger, N., Exporting to Latin America

Hough, B. O., Practical Exporting 
O'Malley, Frank, Our South American Trade and Its Financing (Foreign Com. Ser. No. 3)

Pepper, C. M., American Foreign Trade

Reports of the Bureau of Foreign and Domestic Commerce, Dept. of Commerce (Latin American Division)

Savay, N., The Science of Foreign Trade

Shepherd, W. S., Latin A merica: 168-179

-, Our South American Trade (Political Science Quarterly, Dec. 1909)

South American Supplement, London Times

United States Consular Reports

United States Department of Commerce and Labor Reports

United States House Document No. 154, 59th Congress, 2d session

United States House Document No. 737, 6oth Congress, 2d session (Fisher, Ethnography and Commercial Importance of Latin America and the West Indies)

Verrill, A. H., South and Central American Trade Conditions of Today: 168-197 Wilson, Otto, South America as an Export Field (Sp. Agt. Ser. No. 81, 1914, Dept. of Conmerce)

\section{CHAPTER VII}

\section{HISPANIC AMERICA AND THE WORLD WAR}

I. Economic and political influences of the war

2. Hispanic-American products necessary in the prosecution of the war

3. Efforts to secure sympathy for one or the other group of belligerents; policies of neutrality; cultural factors in the situation; Germany as a menace

4. Improvement in the financial situation; development of Pan Americanism; the financial congresses

5. Growth of anti-German sentiment in certain countries; Ruy Barbosa's indictment of Germany; the Luxburg and Zimmermann dispatches

6. Effect of the entrance of the United States into the war

7. Hispanic America in the war

a. Nations which declared war: Brazil, Costa Rica, Cuba, Guatemala, Haiti, Honduras, Nicaragua, Panamá

b. Nations which severed relations with Germany: Bolivia, Ecuador, Perú, Santo Domingo, Uraguay

c. The neutral countries: Argentina, Chile, Colombia, México, Paraguay, Salvador, Venezuela

d. Services of Brazil and Cuba

8. Hispanic America and the Peace Conference; the prominent part played by Brazil

9. The Tacna-Arica question in a new phase

10. Attitude toward the League of Nations; Brazil as a member of the Supreme Council; the states which joined the League

11. The Monroe Doctrine during the war; projects for an inter-american league of states

12. Economic results of the war upon Hispanic America 


\section{Readings:}

Acosta, A., El doctor Hipólito Irigoyen

Alzamora, I., La cuestión peruano-chilena

Barbosa, Ruy, Brazil in the Hour of Victory (Inter-America 1919)

Bogoño, L. Barros, Tacna and Arica; the Solution of the Question through Its Transfer to Bolivia

Colmo, A., Mi neutralismo

Ferrara, O., La doctrina de Monróe y la liga de las naciones

Gaillard, Gaston, Amérique latine et Europe occidentale

Goldsmith, P. H. (Trans.), South American Opinions on the War (I. Chile and the War, by Carlos Silva Voldósola. II. The Attitude of Ecuador, by Nicólas F. López. Carnegie Endowment for International Peace, Div. for Intercourse and Education, Pub. No. 14)

Gutiérrez, Gustavo, La neutralidad y beligerancia de Cuba durante la guerra actual

Kirkpatrick, F. A., South America and the War

Lavalle, J. B. de, Páginas de historia diflomática contemporánea

Martin, P. A., Latin America and the War (League of Nations, II, No. 4)

Nieto, G. Gallardo, Neutralidad de Chile ante la guerra europea

Quesada, Ernesto, El "peligro Aleman" en Sud América

Rocuant, E., La neutralidad de Chile

Rowe, L. S., Early Effects of the War upon Finance, Commerce and Industry of Peru

The (London) Times History of the War, (Vol. XV).

Wagner, E. R., L'Allemagne et l'Amérique Latine

Yearbooks and periodicals

\section{CHAPTER VIII}

\section{CONTEMPORARY HISTORY, PROBLEMS, AND ACHIEVEMENTS OF HISPANIC AMERICA}

I. Political

a. Political and governmental stability

b. Politics in practice and principle

c. Modern conventions, platforms, and elections

d. Restrictions of the ballot

e. Professional men in politics

f. Absence of political experience by the masses

g. Necessity of developing public interest in politics and political philosophy

h. Appearance of new political issues

i. Electoral reform; Argentina

j. Civil service in Hispanic America

k. State or church control over education

1. Municipal government

(I) History of progress 
(2) Public utilities; fire departments; police system; water works; public sanitation; municipal ownership

m. Social legislation

n. Passing of the South American type of revolution

\section{Readings:}

Alvarez, Agustín, Historia de las Instituciones Libres

Calderón, García, Latin A merica: 222-248, 365-677

Espinosa, Roberto, La evolución democrática

Gonzáles, Enrique Vera y, Elementos de historia contemporánea de América

Heredia, - Memorias sobre las revoluciones de Venezuela

Lima, M. de Oliviera, La evolución de la América latina

Ross, E. A., South of Panama

Scruggs, W. L., The Colombian and Venezuelan Republics

Shepherd, W. R., Latin America: I4 I-I50

2. Social and religious

a. Social

(I) Population

(a) Census statistics available

(b) Population and resources

(2) Social types: Spanish; immigrant; Indian, savage and civilized; mixed races; negro

(3) Laboring classes and types: "vaquero"; "roto"; "pelao"; "Cholo" "gaucho"; "llanero"; industrial laborers

(4) Labor system and laws

(a) Peonage

[I] Feudal status of labor in colonies

[2] Origin of peonage; inheritance of debt

[3] The "inquilino" and "colono"

[4] Ignorance, wages, and living conditions

[5] Peón in government and politics

[6] Peonage in México; in South America

(b) Labor regulations in general

(c) Labor organizations

(d) Dearth of labor in certain countries

(e) Strikes; radicalism; labor conditions in Argentina, Brazil and

México; organized labor; socialist and Bolshevist propaganda

(5) Aristocratic and professional society

(6) Language

(7) Position of woman
(a) In society
(b) Family life
(c) The matter of divorce

(8) Amusements and social customs

(a) Sports and games

(b) Carnivals and festivals

(c) Dress and etiquette 
(d) Gambling and lotteries

(e) Social customs in business

(9) Influence of the Basques in Hispanic America

(I0) The "Gallegos," Catalonians, Andalusians and other Spanish types in modern Hispanic America

Readings:

Bingham, Hiram, Across South America

Bland, J. O. P., Men, Manners and Morals in South America

Bryce, James, South America: 432, 528-530

Bunge, O. C., Nuestra América

Calderón, García, Latin America: 283-290

Colmo, A., América latina

Dickman, E., Democracia y socialismo

Ruzo, A., Política social

Shepherd, W. R., Latin America: 12 I-I4I

- Psychology of the Latin American (Journal of Race Development, 1919)

Solas, J. C., Civilización y barbarie

Vera Estañol, Jorge, Carranza and his bolshevik régime

Zavalea, C., Defensa social de nación

b. Religious

(I) Prevalence of Roman Catholic church

(2) Church and state; tendency toward separation

(3) Clericalism in politics

(4) The work of the church

(5) Toleration in Hispanic America

(6) Protestant missionary activities

(7) Foreign opinion of Hispanic-American morality

(8) Work of the Catholic church in education and charity

Readings:

Ayarragaray, Lucas, La iglesia en América

Brown, H. W., Latin America

Klein, Julius, The Church in Spanish American History (Catholic Historical Review, 1917)

Koebel, W. H., The South Americans: 4I-44, 9I-I08, I52-I69

Lee, John, Religious Liberty in South America

Neely, T. B., South America, Its Missionary Problems

Speer, R. E., South American Problems

3. Immigration

a. History of immigration in the nineteenth century

(I) Causes of scarcity before 1857; colonial exclusion; revolutions; greater inducements of the United States; economic reasons

(2) Increase since 1857; ideas of Alberdi and Sarmiento on immigration

(3) Drift toward the southern republics

(4) Immigration in the North American republics

b. Political and economic eff ects of immigration

c. Effects on society 
d. Spanish, Italian, German, Russian and Polish, English, French, Portuguese, Oriental, Turkish and Syrian immigration

e. Favorite occupations of aliens

f. The question of assimilation and citizenship

Readings:

Athas América-latina

Berne, P., L'immigration europienne en Argentina

Calderón, García, Latin America: 290-298, 323-33.5

Koebel, W. H., The South Americans: 152-169

British Exploits: 481-55I

Mulhall, The English in South A merica

Shepherd, W. R., Latin America: 81-84, 126-129, 169

Villegas-Pulidos, G. T., Los extranjeros en Venezueia

Wintzer, Dic Deutschen im tropischen Amerika

4. Financial

a. Monetary systems in Hispanic America

(I) Standards and values

(2) Paper currency

(3) Fluctuations

b. Capital and banking

(1) Number of banks

(2) Domestic and foreign control of banking

(3) Branch banks

(a) European

(b) United States

(4) Scarcity of capital

c. Hispanic-American finance

(1) Credits, exchange, solvency

(2) Stock exchanges

(3) Bond issues

(4) Public debts

(5) Sinking funds

(6) Insurance

(7) Trusts and corporations

d. Foreign influences upon financial policies

e. Business enterprises

(I) Habits of business

(2) Buying and selling; advertising

f. Tariff systems

(I) Tariff for revenue

(2) Rates: specific rather than ad valorem

(3) Variations and complexity

g. Taxation

(I) On personal property

(2) On lands and real estate

(3) On industries

(4) Licenses and concessions 
h. Internal improvements and public works

(I) History of internal improvements in Hispanic America

(2) Public works; postal service; parcel post

i. Movement for single, Pan American monetary standard

j. Movement for Pan American, standardized tariff system

Readings:

Aughinbaugh, W. E., Selling Latin America

Babson, R. W., The Future of Latin America

Crosby, Latin American Monetary System and Exchange Conditions

Hurley, Banking and Credit in Argentina, Brazil, Chile and Peru (Sp. Agts. Ser.

No. 90, 1914, Dept. of Commerce)

Reports of the Board of Trade (Eng.)

Roper, The Postal Service and the Latin American Trade

Shepherd, W. R., Latin America: 47-48, 150-153, I73

South American Year-Book

United States Consular Reports

Verrill, A. H., South and Central American Trade Conditions of Today

Williams, J. H., Argentine International Trade under inconvertible Paper Money

Wolfe, Foreign Credits (Sp. Agts. Ser. No. 62, 1913, Department of Commerce)

5. Industrial

a. The most important industries

(I) Mining
(a) Areas of ore fields
(b) Facilities
(c) Acquisition of mining properties
(d) Labor supply; laws regulating labor in mines
(e) Gold, silver, diamonds, copper, tin, nitrate, coal, and other mines

(2) Stock-raising
(a) Areas adapted
(b) Cattle, horse, sheep ranches
(c) Stock-yards and slaughter-houses
(d) Wool and hides

Readings:

\section{Atlas América-latina}

Whelpey, Trade Development in Argentina (Sp. Agts. Ser. No. 43, 191 I, Department of Commerce and Labor)

(3) Rubber
(a) Areas of growth
(b) Processes employed
(c) Labor supply; labor scandals; "black gold"

(4) Agriculture
(a) Arable lands and climatic conditions
(b) Agriculture in connection with stock-raising
(c) Ownership of land
(d) The agrarian situation in Hispanic America 
(e) The "haciendas," "fazendas;" the "chacras" and "potreros"

(f) Agricultural products: coffee, cacao, yerba, foodstuffs

(5) Manufacturing

(a) General characteristics: domestic and factory methods

(b) Connection with other indust ries

(c) Obstacles in the way

(d) Products: foodstuffs, textiles, machinery

b. European and American capital invested in industries

c. Occupations of foreigners in Hispanic America

Readings:

Gemmingen, —- Die Entwickelung der Fabrikindustrie im latinischen Amerika

Holm, G., The Argentine Grain Growers' Grievances

Koebel, W. H., The Soulh Americans: 132-151, 193-204

Pearson, H. C., The Rubber Country of the Amazon

6. Commercial

a. History of Hispanic-American commerce

b. Exports and imports

(I) Character and value

(2) Destination

c. Commercial enterprises

d. Trade marks and their use

e. Customs regulations

f. Modern transportation and communication

(I) Development of transportation facilities

(2) Survival of colonial methods in certain areas

(3) Pack trains, stage routes, llama trains

(4) Roads and highways

(5) Land transportation

(a) Railroads: trunk lines; short lines

(b) International and transcontinental lines

(c) Projected lines

(d) Horse cars and trolleys; subways

(e) Mileage and rates

(f) Freight rates

(g) Capital and ownership

(6) Water transportation

(a) River steamers and barges

(b) Oceanic lines

(c) Harbor facilities

(d) Rates

g. Communication

(I) Telegraph lines

(2) Cable lines

(3) Postal service; international service

h. The metric system of weights and measures

i. Concessions and monopolies

(1) Procedure in obtaining them 
(2) Policies of various countries in relation thereto

(.3) Attitude of the United States toward them

Readings:

Atlas América-latina

Aughinbaugh, W. E., Selling Latin America

Babson, R. W., The Future of Latin America

Domville-Fife, Great States of South America

Gueydan. Transportation Facilities of Colombia and Venezuela. (Dept. of Commerce

Koebel, W. H., The South Americans: 304-358

Report of the Bureau of Foreign and Domestic Commerce of the Commerce Department

Reports of Bureau of Trade Relations of the State Department

Shepherd, W. R., Latin America: r68-19I

Sheridan, Transportation Rights to the West Coast of South America (Sp. Agts. report Ser. 72, 1913. Bur. of For. and Dom. Commerce)

Tariff Systems of South American Countries (Bur. of For. and Dom. Com.)

Trade Mark Registration in Latin America (Tariff series, No. 31, ibid.)

United States Federal Trade Com. Rep. on Trade and Tariffs in Brazil, Uruguay, Argentina, Chile, Bolivia and Peru

Verrill, A. H., South and Central American Trade Conditions of Today

7. Educational and cultural

a. Educational

(I) General characteristics

(2) Percentages of illiterates in various countries

(3) Educational progress

(4) Obstacles to popular education

(5) Foreign influences in education

(a) European teachers in Hispanic America

(b) American teachers in Argentina in 1868; educational reforms of Sarmiento

(c) Influence of United States at present

(6) Administration of schools

(7) Elementary and secondary education

(8) Higher education in Hispanic America

(a) Universities

[I] Faculties, courses, and equipment

[2] Libraries and publications

[3] Students

(b) Scientific pursuits

[I] Observatories and other establishments for study of geography, ethnology, and zoology

[2] Schools of medicine and surgery

(c) Industrial and technical education

(9) Urban and rural education

(Io) Popular interest in education 
(11) Non-official efforts for promotion of education

(a) Congresses and teachers' associations

(b) Private schools and institutions

(c) Publications and lectures

(12) Educational reforms needed

b. Cultural achievements in general

(1) Public charity

(a) Control and sources of revenue

(b) Societies and institutions for social service

(2) Public libraries

(3) Journalism

(a) Status of the press in various countries

(b) Notable newspapers

(c) Recent development

(d) Magazines and periodicals

(4) Literature

(a) General characteristics

(b) European, and particularly French, influence

(c) Representative literary men and their works

[1] Novelists, essayists, poets

Ricardo Palma; Rodó, Alencar, Gonzálvez Díaz, Zorrilla de San Martín, Echeverría, Sarmiento, Rubén Darío, Chocano, Blanco Fombona, etc.

[2] Historians

Alamán, the Amunátegui, Barros Arana, Genaro García, Icazbalceta, Vicuña Mackenna, Mitre, José Toribio Medina, Oliviera Lima, etc.

[3] Jurists

Bello, Calvo, Vélez Sarsfield, Ambrosio Montt, etc.

(5) Arts

(a) General characteristics

(b) Achievements in music; the drama; architecture; painting; and sculpture

Readings:

Alvarez, Agustìn, Educación moral

Amedeo, Tomás, Agricultural Instruction in Argentina (Bull., Pan Amer. Union, 1920)

Amunátegui, M. L., La alborada poética en Chile

Amunátegui, Solar, D., Bosquejo histórico de la literature chilena

Blakeslee, G. H., (ed.) Latin America: 30-46, 299-306

Brandon, E. E., Latin American Universities and Special Schools (United States

Bureau of Education, bulletin, No. 30), 1912

Calderón, García, Latin America: 249-282

Coester, Alfred, The Literary Iistory of Spanish America

Eder, P. J., Colombia: Chap. 16

Goldberg, Isaac, Studies in Spanish American Literature

Hirst, W. A., Argentina: Chap. 14 
Henrìquez Ureña, M., Rodó y Rubén Darío

Koebel, W. H., The South Americans: 109-132

Lamborn, - Mexican Paintings and Painters

López, Zanelli, Mujeres chilenas de letras

Mejì, E. Bravo, Organización de las escuelas rurales

Mitjans, Aurelio, Historia de la literatura cubana

Monroe, Paul, An Encyclopedia of Education (see discussion under the names of each country)

Oyuela, Calixto, Antología poética hispano-américane (3 vols.)

Shepherd, Latin America: 192-250

- Education in South America (Rev. of Rev., May, 1908)

- Higher Education in South America (Columbia University Quarterly, Dec., 1907)

- La literatura y el periodismo

Starr, F., Readings from Modern Mexican Authors

Umphrey, Spanish American Poets of Today and Yesterday (Hispania, 1919)

Uriarte, Ramón, Galería poética centro-americana (3 vols.)

Walle, Paul, Bolivia: Chap. 6

Warner, Library of the World's Best Literature: Vol. I5

Wright, M. R., Bolivia

- The Old and the New Peru

-, The Republic of Chile 


\section{PREVIOUS PUBLICATIONS}

1919

Announcement of Founding of Institute.

1920

Bulletin No. I. First Annual Report of the Director.

Bulletin No. 2. For Administrative Authorities of Universities and Colleges.

Bulletin No. 3. Observations on Higher Education in Europe.

Opportunities for Higher Education in France.

Opportunities for Graduate Study in the British Isles.

\section{For the International Relations Clubs}

Syllabus No. I. Outline of the Covenant of the League of Nations.

Syllabus No. II. The Past, Present and Future of the Monroe Doctrine.

Syllabus No. III. The History of Russia from Earliest Times.

Syllabus No. IV. The Russian Revolution.

Syllabus No. V. The Question of the Balkans.

Syllabus No. VI. Modern Mexican History.

Syllabus No. VII. Hispanic-American History.

\section{I92 I}

Bulletin No. 1. Second Annual Report of the Director.

Bulletin No. 2. Opportunities for Higher Education in Italy.

Bulletin No. 3. Serials of an International Character

(Tentative List for Libraries)

Bulletin No. 4. Educational Facilities in the United States for South African Students.

Bulletin No. 5. Guide Book for Foreign Students in the United States. 
) 



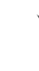




\section{ADVISORY COUNCIL}

Addams, Jane

Alderman, President Edwin

Ames, Dean Herman V.

Andrews, Fanny Fern

Biggs, Dr. Herman

Blakeslee, Professor G. H.

Brookings, Robert S.

Bruère, Henry

Bull, Dr. Carroll G.

Burton, President M. L.

Byrne, James

Coolidge, Professor Archibald

Cravath, Paul D.

Cunliffe, Professor J. W.

Davis, Katherine B.

Downer, Professor Charles A.

Ely, Professor Richard T.

Filene, A. Lincoln

Finley, Dr. John $\mathrm{H}$.

Fosdick, Dr. Harry E.

Gilbert, Cass

Gildersleeve, Dean V. C.

Goodnow, President F. J.

Hadley, Dr. A. T.

Hale, Dr. George E.

Harrington, Governor E. C.

Hazen, Professor Charles D.

Hibben, President J. G.

Howe, Professor Henry M.

Hughes, Hon. Charles E.

Jenks, Professor Jeremiah

Judson, President H. P.

Keppel, Frederick P.

Keyser, Professor C. J.

Lovett, President Edgar

Lowell, President A. L.

MacCracken, President H. N. Woodbridge, Dean F. J. E.

Mali, Pierre

Main, President J. H. T.

Mannes, David

Marling, Alfred E.

Meiklejohn, President A.

Milliken, Professor R. A.

Moore, Professor E. H.

Morgan, William Fellowes

Neilson, President W. A.

Noyes, Professor Arthur A.

Payne, President Bruce R.

Pendleton, President Ellen T.

Pupin, Professor Michael I.

Putnam, Herbert

Richardson, Dr. E. C.

Robinson, Dr. Edward

Sachs, Professor Julius

Salmon, Dr. Thomas W.

Schwedtman, Ferdinand C.

Severance, Mrs. C. A.

Shanklin, President W. A.

Shorey, Professor Paul

Shotwell, Professor J. T.

Showerman, Professor Grant

Stimson, Henry L.

Stokes, Dr. Anson Phelps

Storey, Professor Thomas A.

Suzzallo, President Henry

Thomas, President M. Carey

Todd, Professor Henry A.

Townsend, Hon. John G.

Vincent, Dr. George E.

Wald, Lillian D.

White, Professor Henry C.

Wilkins, Professor Ernest H.

Wilson, Professor George G.

Woolley, President Mary E. 
